\title{
Rho Guanine Nucleotide Exchange Factor
} 10

National Cancer Institute

\section{Source}

National Cancer Institute. Rho Guanine Nucleotide Exchange Factor 10. NCI Thesaurus. Code C147568.

Rho guanine nucleotide exchange factor 10 (1369 aa, $152 \mathrm{kDa}$ ) is encoded by the human ARHGEF10 gene. This protein plays a role in guanine nucleotide exchange and peripheral nerve myelination. 